\title{
Inorganic Elements of Mangium Stem (Acacia mangium Willd) from Different Provenances
}

\author{
Ganis Lukmandaru, Vendy Eko Prasetyo, and Widyanto Dwi Nugroho
}

\begin{abstract}
This study aimed to investigate the ash content and concentrations of inorganic elements present in the stem of Acacia mangium. The tree samples (24 years) were collected from five different provenances (Sidei, West of Morehead, Daintree, Ellerbeck, and El Arish). Meanwhile, the disc samples were obtained from the trunk of each tree on the lower parts. The samples were collected from four radial positions (bark, sapwood, outer heartwood, inner heartwood), and the ash and insoluble acid contents were determined. Furthermore, the concentration of 5 elements $(\mathrm{Ca}, \mathrm{Mg}, \mathrm{Fe}, \mathrm{Mn}, \mathrm{K}$, and $\mathrm{Na}$ ) was measured by Atomic Absorption Spectrophotometry (AAS). The interaction of provenance and radial position factors affected ash and potassium contents. Also, acid insoluble ash and calcium contents showed a provenance factor effect. The barks obtained from the tree samples contained the highest concentrations of ash content and most of the elements. The wood and bark of El-Arish provenance showed the lowest (0.50 0.72\%) and highest levels $(4.75 \%)$ of ash content respectively. Furthermore, the highest amount of insoluble acid ash (3075 ppm) and calcium (4513 ppm) content was also measured in samples of El-Arish provenance, and radial position factor was a significant source of variation for $\mathrm{Ca}, \mathrm{Mg}, \mathrm{Na}$, and $\mathrm{Mn}$ concentrations. Except $\mathrm{Mg}$, the inner and outer portions of the heartwood mostly showed no significant difference in unprecedented element concentrations. Ash content was positively correlated with $\mathrm{Ca}$ in sapwood $(\mathrm{r}=0.39)$ and $\mathrm{Mn}$ in bark $(r=0.54)$. In addition, moderate correlations were observed between $\mathrm{Mg}$ and $\mathrm{Ca}$ in heartwood $(r=0.63)$ and bark $(r=0.54)$ tissues. For ash and silica content, the comparatively low concentration on samples from El-Arish provenance are good options to improve wood quality for breeding programs.
\end{abstract}

Keywords: trace elements, silica, tree breeding, fast-growing, wood chemistry, mangium (Acacia mangium).

\section{Introduction}

Mangium (Acacia mangium) is one of the most important timber plant commodities in the tropics. In Indonesia, this species is planted on a large scale through the Forest Estate Timbers program due to its fast growth, good adaptability, high resistance to diseases, and multipurpose uses. Primarily, the mangium wood is used by the pulp and paper industries, especially at a young age.

Furthermore, the rise in the consumption of wood products has tremendously increased the demand for mangium. The wood is used as an alternative for non-pulp products (furniture, veneers, sawn-timbers, and other products) by extending its rotation cycle to meet the commercial size of the tree. Meanwhile, several studies have focused on assessing the feasibility of mangium wood and bark for panel construction as well as adhesive production (Korai et al. 2000; Yano et al. 2003; Firmanti et al. 2007; Subyakto et al. 2003; Subyakto et al. 2005). The properties of this wood are undoubtedly affected by its inorganic or mineral components, for instance, the high silica contents cause deterioration of the cutting tools (Shmulsky and Jones 2011) and resistance to damage caused by insects as well as marine borers (De Silva and Hillis 1980). In addition, other major inorganic components cause wood adhesion (Kanazawa et al. 1978), blackening (Takahashi 1996; Minato and Morita 2005), and tree growth (Kuhn et al. 1997).
Regarding raw materials, few studies have measured the quality of mangium based on its origin or tree breeding. Furthermore, the difference in seed source and the influence of climate affect the properties of wood. Previous studies based on tree geographical or differences in provenance have compared chemical properties and fiber dimensions of mangium wood (Syafii and Siregar 2006; Raphy et al. 2011) the wood's physical and mechanical properties (Hadjib et al. 2007). In the tree breeding programs for the production of high-quality raw materials, it is important to consider the properties of wood as a basis of selection criteria. There is little information on the chemical properties of mangium wood, particularly with regard to breeding programs. In addition, the inorganic components of mangium wood is less explored. Previous reports have examined the color, anatomical, and various chemical properties of mangium wood (Lukmandaru et al. 2011a, 2011b; Lukmandaru 2012; Nugroho et al. 2012). Therefore, this research aimed to determine variations in the value of inorganic matter content based on differences in provenance and radial direction. In addition, the degree of relationship between inorganic substance parameters was also analyzed.

\section{Materials and Methods}

\section{Plant Materials}

The "Provenances Trial Site" for mangium is located in the Wanagama Educational Forest, Gunungkidul Regency, 
Jogjakarta Province (1100 30'38" $110^{\circ} 33^{\prime} 03^{\prime \prime} E$ and $7053^{\prime}$ 25 " 70 54'52" S). The seeds were collected from several different provenances and seedlings were planted in 1984. The planting was conducted in a batch of five trees with a 4 $x 4 \mathrm{~m}$ spacing in a full block design. Five straight trees (24 years, diameter range of 13-38 cm, with a tree height of 10$25 \mathrm{~m}$ ), grown from the five provenances of Acacia mangium trees (compartment no. 17) were felled. The provenances were Sidei Papua (Indonesia), West of Morehead (Papua New Guinea), Daintree, Ellerbeck Red Cardwell, and El Arish (Queensland, Australia). The sample was a $5 \mathrm{~cm}$ thick disk cut at the base of the tree, and the bark of the stem was separated from the wood. Furthermore, each disc was subdivided into 4 sections in the radial direction i.e bark, sapwood, as well as outer and inner heartwood. Each section from two opposing radii was converted into wood powder by drilling and was combined to form a single sample.

Measurements of Ash, Insoluble Acid Ash, and Inorganic Elements Contents

To determine the ash content, the wood samples $(2 \mathrm{~g}$, oven-dry wood) were subjected to calcination in a muffle furnace around $600^{\circ} \mathrm{C}$ according to ASTM D-1002 (2002). The ash content is calculated on the basis of the initial weight percentage of the powder. It was then treated with 12 $\mathrm{M} \mathrm{HCl}$ to dissolve the silica according to TAPPI (1992). To completely evaporate the silica in the solution, it was reignited in the muffle furnace at $600^{\circ} \mathrm{C}$. The Shimadzu 6200 atomic absorption spectrophotometer (AAS) (flame emission) was used to determine the elements of ash content, namely calcium $(\mathrm{Ca})$, magnesium $(\mathrm{Mg})$, iron $(\mathrm{Fe})$, manganese $(\mathrm{Mn})$, potassium $(\mathrm{K})$, and sodium $(\mathrm{Na})$.

\section{Statistical Analysis}

An analysis of variance (two-way) was performed using SPSS version 10.0. The effect of provenance and radial direction on the measured parameters assayed as a normal data distribution was calculated in the general linear model (95\% confidence level). The Duncan multiple series tests were also applied for posthoc analysis. Also, correlation analysis (Pearson) was performed to evaluate the influence of silica and other elements on the ash content.

\section{Results and Discussion}

\section{Ash and Acid Insoluble-ash Contents}

The metals in the ash come in the form of various salts including oxalates, phosphates, silicates and other minerals (Sjostrom 1981). The ash content value obtained from this study (Table 1) $(0.5 \sim 1.1 \%)$ was higher than the previous record $(0.2 \%)$ and $0.6 \%$ for hybrid acacias (CABI 1996). Meanwhile, the high value is probably due to the older mangium trees used. The ANOVA of ash content showed that there were a significant provenance and radial position interaction (Table 2). On the contrary, the values of ash content between sapwood and heartwood were slightly different while the bark showed the highest values (Table 1). Bark samples had a greater content of ash than sapwood or heartwood, and this result was similar to the reports of Shanavas and Kumar (2003); Tsuchiya et al. (2010); Martinez-Pérez et al. (2015).

The values in the inner heartwood area reached $1.55 \%$ and were in the range of $1.0 \sim 1.5 \%$ in the samples of Daintree, Sidei, and Ellerbeck provenances (Table 1). Generally, the smallest average values were obtained in the samples of El-Arish provenance both in sapwood $(0.57 \%)$ and heartwood (0.50 0.72\%). However, the highest level $(4.75 \%)$ was observed for bark at the same provenance. The amount of ash content that has declined from heartwood to sapwood was observed in Daintree, Sidei, and Ellerbeck provenances.

Measurement of insoluble acid ash content was used to determine the silicate and silica contents in wood (TAPPI 1992). Unlike the ash content, the insoluble acid parameter did not show interactions on both factors even though it had a significant effect. Furthermore, Daintree and bark tissue samples had the highest values among provenances and radial position respectively (Figure 1.) A high value is certainly not expected in woodworking since silica causes metal tools to become dull (Shmulsky and Jones 2011). ANOVA showed that genetic factors are affecting the value of the ash and insoluble acid contents since the trees are planted on relatively homogeneous sites. Previously, the provenance factor significantly affected color properties but not for extractive contents, $\mathrm{pH}$ values, and buffer capacities of mangium wood (Lukmandaru et al. 2011a, 2011b; Lukmandaru 2012). In addition, following the wood anatomical properties, Sidei and Daintree are more appropriate provenances among those examined for the Acacia mangium tree breeding programs in Indonesia (Nugroho et al. 2012). Due to low values of ash and silica contents, this finding suggests El-Arish provenance will improve wood quality in future breeding programs. 
Table 1. Ash and inorganic element contents (\% dry-wood weight) of $A$. mangium stem by provenance and radial position.

\begin{tabular}{|c|c|c|c|c|c|c|c|c|c|}
\hline Provenances & Positions & Ash (\%) & AIC (ppm) & $\mathrm{Ca}(\mathrm{ppm})$ & K (ppm) & $\mathrm{Mg}(\mathrm{ppm})$ & $\mathrm{Na}(\mathrm{ppm})$ & $\mathrm{Fe}(\mathrm{ppm})$ & Mn (ppm) \\
\hline \multirow[t]{4}{*}{ Daintree } & Inner heartwood & $1.26(0.18) c$ & $940(592)$ & 485(197) & $145(66) \mathrm{g}$ & $178(51)$ & 144(83) & nd & $0.08(0.04)$ \\
\hline & Outer heartwood & $1.01(0.23) \mathrm{c}$ & $5800(275)$ & 1296(432) & $130(85) \mathrm{g}$ & $282(33)$ & $168(67)$ & nd & $0.05(0.01)$ \\
\hline & Sapwood & $0.93(0.17) d$ & $910(178)$ & $132(33)$ & $252(0.4) f$ & $287(52)$ & $39(26)$ & nd & $0.25(0.03)$ \\
\hline & Bark & $2.93(0.65) \mathrm{b}$ & $4000(868)$ & 11746(5764) & $250(0.8) f$ & $377(62)$ & $70(16)$ & 196(328) & $1.41(1.10)$ \\
\hline \multirow[t]{4}{*}{ Sidei } & Inner heartwood & $1.55(0.57) c$ & 1290(815) & $470(416)$ & $208(28) f g$ & 231(64) & $152(26)$ & $35(70)$ & $0.11(0.05)$ \\
\hline & Outer heartwood & $1.06(0.22) \mathrm{cd}$ & $1860(688)$ & $766(582)$ & $311(235) \mathrm{e}$ & 246(84) & 136(94) & $26(42)$ & $0.84(0.05)$ \\
\hline & Sapwood & $0.85(0.01) \mathrm{cd}$ & $337(175)$ & $136(116)$ & $252(548) f$ & $287(52)$ & $52(16)$ & $501(1120)$ & $0.62(0.88)$ \\
\hline & Bark & $2.70(0.45) \mathrm{b}$ & $4412(1506)$ & $3919(4703)$ & $210(78) f g$ & $257(173)$ & $61(4)$ & $28(16)$ & $0.99(1.06)$ \\
\hline \multirow[t]{4}{*}{ Ellerbeck } & Inner heartwood & $1.18(0.16) c$ & 1287(979) & $484(249)$ & $164(75) f g$ & 194(91) & 159(31) & nd & $0.11(0.07)$ \\
\hline & Outer heartwood & $1.10(0.15) c$ & $2037(705)$ & $542(387)$ & $148(71) \mathrm{g}$ & 174(113) & $126(50)$ & $9(21)$ & $0.06(0.02)$ \\
\hline & Sapwood & $0.69(0.21) d$ & $1420(256)$ & 1918(4093) & $251(0.8) f$ & $270(62)$ & $35(24)$ & $23(53)$ & $0.23(0.07)$ \\
\hline & Bark & $2.84(0.28) b$ & $4712(867)$ & $4662(3269)$ & $249(0.5) f$ & 346(87) & $38(27)$ & $92(67)$ & $1.06(0.53)$ \\
\hline \multirow[t]{4}{*}{ West of Morehead } & Inner heartwood & $0.68(0.08) \mathrm{cd}$ & 1010(483) & $606(219)$ & $40(15) \mathrm{h}$ & 139(69) & $112(47)$ & $2(1.87)$ & $0.08(0.03)$ \\
\hline & Outer heartwood & $0.86(0.23) \mathrm{cd}$ & $1300(1064)$ & $623(406)$ & $49(26) \mathrm{h}$ & $207(60)$ & $105(26)$ & nd & $0.08(0.01)$ \\
\hline & Sapwood & $0.75(0.13) \mathrm{cd}$ & 1220(315) & 1759(3739) & $251(0.5) f$ & $278(50)$ & $43(25)$ & $0.80(0.83)$ & $0.22(0.07)$ \\
\hline & Bark & $2.52(0.79) \mathrm{b}$ & $4025(567)$ & $8132(6218)$ & $248(1) f$ & $329(48)$ & $49(6)$ & $54(37)$ & $1.17(0.03)$ \\
\hline \multirow[t]{4}{*}{ El Arish } & Inner heartwood & $0.50(0.49) d$ & 1366(802) & $344(291)$ & $240(113) f$ & $184(148)$ & 137(74) & $9(12)$ & $0.08(0.02)$ \\
\hline & Outer heartwood & $0.72(0.35) c$ & 1375(742) & $547(470)$ & $186(134) \mathrm{g}$ & $110(94)$ & 101(81) & $10(24)$ & $0.22(0.12)$ \\
\hline & Sapwood & $0.57(0.15) d$ & $1600(141)$ & $5852(6170)$ & $240(0.5) f$ & $266(43)$ & $65(19)$ & $36(29)$ & $1.27(1.19)$ \\
\hline & Bark & $4.75(0.23) a$ & $5960(1046)$ & $11309(7772)$ & $248(1) f$ & $373(63)$ & $45(4)$ & $384(476)$ & $0.52(0.84)$ \\
\hline
\end{tabular}

Remarks: $\mathrm{AIA}=$ acid insoluble ash content; $\mathrm{Ca}=$ calcium; $\mathrm{K}=$ potassium; $\mathrm{Mg}=$ magnesium; $\mathrm{Na}=$ sodium; $\mathrm{Fe}=$ iron; $\mathrm{Mn}=$ manganese. Mean of 5 trees (24 years), with the standard deviation in parentheses. The same letters on the same column are not significantly different at $p<5 \%$ by Duncan's test.

Table 2. Provenance and radial direction analysis of variance in ash and inorganic element contents

\begin{tabular}{|c|c|c|c|c|c|c|c|c|}
\hline \multirow[b]{2}{*}{ Source of variation } & \multirow{2}{*}{$d f$} & \multicolumn{7}{|c|}{ Mean square } \\
\hline & & Ash & AIA & Calcium & Potasium & Magnesium & Sodium & Manganese \\
\hline Provenance $(\mathrm{A})$ & 4 & $0.4^{* \star}$ & $2397492^{* *}$ & $30406691^{*}$ & $26745^{\star *}$ & 7052 & 1721 & 0.410 \\
\hline Radial position (B) & 3 & $27.9^{* *}$ & $62446559^{* *}$ & $275166497^{\star *}$ & $55817^{\star *}$ & $109977^{* *}$ & $45892^{* *}$ & $3.680^{\star *}$ \\
\hline$A \times B$ & 12 & $1.58^{* *}$ & 901570 & 19560868 & $14745^{* *}$ & 10028 & 1272 & 0.266 \\
\hline Error & 74 & 0.1 & 533908 & 11449470 & 5756 & 6647 & 2521 & 0.268 \\
\hline
\end{tabular}

Remark: AIA = acid insoluble ash content, ${ }^{* *}$ Significant at the $1 \%$ level; ${ }^{*}$ significant at the $5 \%$ level
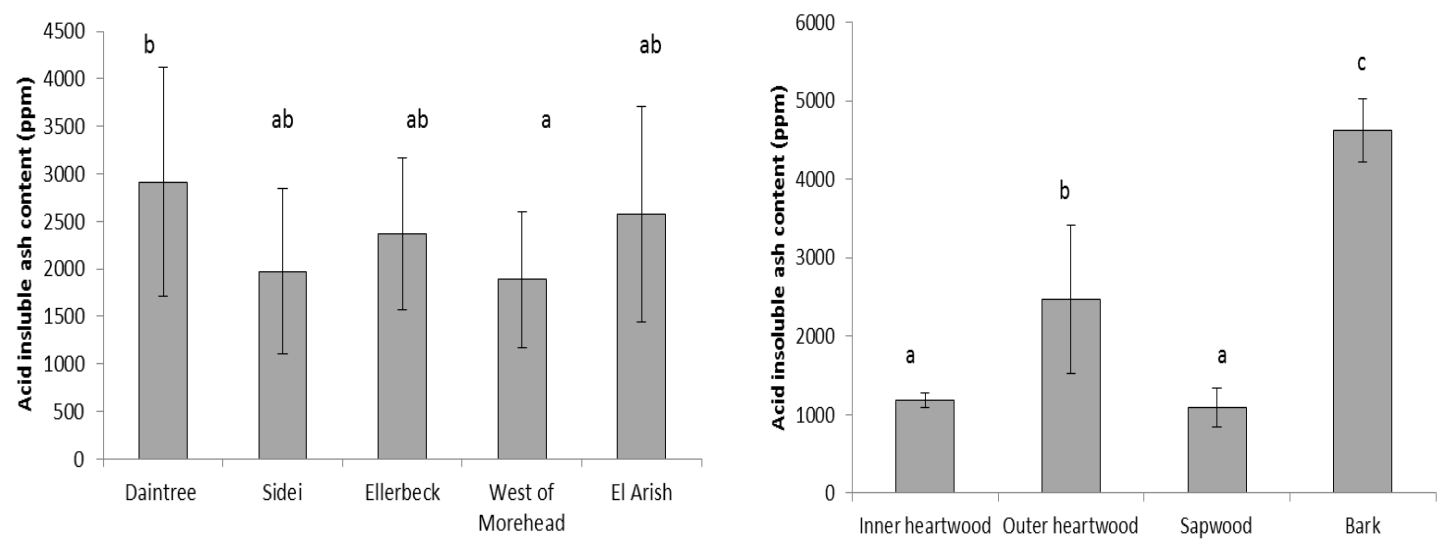

Figure 1. Acid insoluble ash content (ppm) of Acacia mangium stem by provenance and radial position. Mean of 5 trees $(24$ years), with the standard deviation in the error bar. The same letters are not significantly different at $p<5 \%$ by Duncan's test.

\section{Inorganic Elements}

The high content inorganic elements observed were $\mathrm{Ca}, \mathrm{K}$, and $\mathrm{Mg}$, commonly found in wood (Fengel and Wegener 1984). Generally, Ca was the most abundant element followed by $\mathrm{K}$ or $\mathrm{Mg}$ while the least was $\mathrm{Mn}$ (Table
1), and Fe was not detected in several parts. High Ca levels were caused by the presence of Ca-oxalate crystals in sieve cells and longitudinal parenchyma (Fengel and Wegener 1984). The obtained values for the $K$ concentration was lower but $\mathrm{Ca}, \mathrm{Mg}$, and $\mathrm{Fe}$ were in the range compared to those of teak wood (Lukmandaru et al. 2009). 
The ANOVA of $\mathrm{K}$ content showed significant provenance and radial position interaction, indicating that their effects are varied (Table 2). Furthermore, the sapwood and bark regions exhibited a higher $\mathrm{K}$ concentration than the heartwood for samples from Daintree, Ellerbeck, and west of Morehead (Table 1). The maximum levels are obtained in the outer sapwood of Sidei provenance (311 ppm), while the lowest was found in the inner heartwood of West of Morehead provenance $(40 \mathrm{ppm})$. Moreover, the ANOVA showed that a significant effect of the provenance factor was obtained in Ca content. According to Duncan's test, $\mathrm{Ca}$ contents in the El-Arish samples were significantly higher compared to those of Sidei provenance (Figure 2). Also, significant differences between the $\mathrm{Ca}$ content and the silica content were obtained in teakwood (Kjaer et al. 1999). Theoretically, the functions of $\mathrm{K}$ in plants is mainly for electrochemical role whereas $\mathrm{Ca}$ has a mechanical function in the cell wall (Okada et al. 1987). However, the exact economic significance of the $\mathrm{Ca}$ and $\mathrm{K}$ content is unknown. In the future, the wide range measured in this study should be considered in the breeding program. The radial positioning factor significantly influenced the content of $\mathrm{Ca}$, $\mathrm{Mg}, \mathrm{Na}$, and $\mathrm{Mn}$ (Table 2), while Fe showed no normal distribution. Okada et al. (1993a, b) observed three patterns of radial nutrient distribution on wood. Type 1 showed element concentrations increased outward from the pith across the heartwood-sapwood boundary, while the pattern was reversed in Type 2. Furthermore, there was a peak in element concentration at the heartwood sapwood boundary in Type 3. The pattern $\mathrm{Mg}$ content was Type $1, \mathrm{Na}$, and $\mathrm{K}$ were Type 2 (Fig. 3), while Fe (Sidei provenance only) and $\mathrm{Mn}$ were Type 3 (Fig. 4). The highest levels of $\mathrm{K}, \mathrm{Mn}$, and $\mathrm{Na}$ in cortical tissue were observed with Duncan's test.

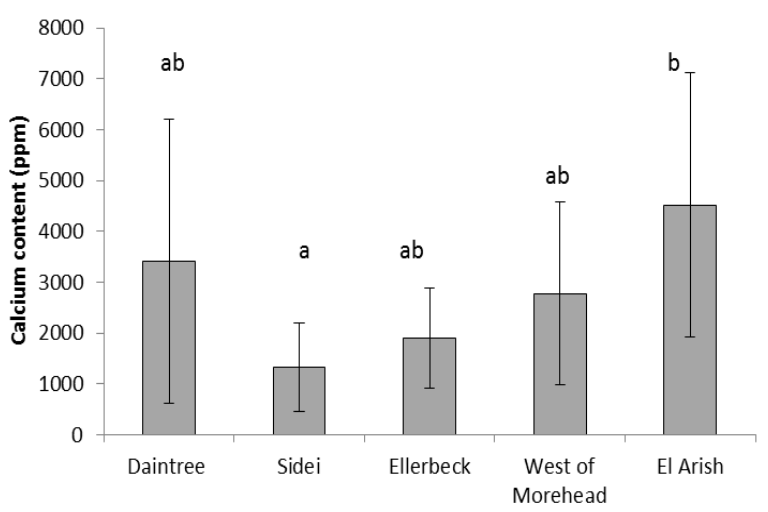

Systematic differences among the different radial directions were not observed for $\mathrm{Ca}$ content because of the less mobile element. $\mathrm{Mg}$ and $\mathrm{Ca}$ are adsorbed on negatively charged exchange sites or incorporated in the form of pectates or the lignin matrix (Meerts 2002). Na and K, which belong to the alkali metal in the periodic table, showed a similar radial distribution pattern, and a slightly different pattern was observed between $\mathrm{Ca}$ and $\mathrm{Mg}$ (alkaline earth metal). The radial distribution pattern of $\mathrm{Fe}, \mathrm{Ca}$, and $\mathrm{Mn}$ levels are in accordance with that of sugi wood but not for $\mathrm{Na}$ content (Okada et al. 1987). In Robinia pseudoacacia wood, the content of $\mathrm{Ca}, \mathrm{Mg}$, and $\mathrm{Na}$ increased from the heartwood to the sapwood (Passialis et al. 2008).

Generally, no significant differences were observed between the inner and outer heartwood parts. This is probably since there is no living tissue in the heartwood and no physiological reaction has occurred (Okada et al. 1987). Furthermore, the difference concentration in several inorganic elements is thought to be related to the heartwood formation such as phenolics formation and $\mathrm{pH}$ value changes. The high level of $\mathrm{Na}$ in the heartwood (Figure 3) may be related due to counter ions for phenolics (weak acid). In addition, high levels of $\mathrm{K}, \mathrm{Mg}$, and $\mathrm{Mn}$ in the sapwood are assumed to be related to their role as cofactors in enzymatic reactions in the cytoplasm (Kramer and Kozlowsky 1960; Okada et al. 1987). The concentrations of $\mathrm{Mg}$ increased significantly from inner heartwood towards bark which is probably due to the decrease in wood cation binding capacity due to the ageing of cells and a decrease of pectic material (Meerts 2002).

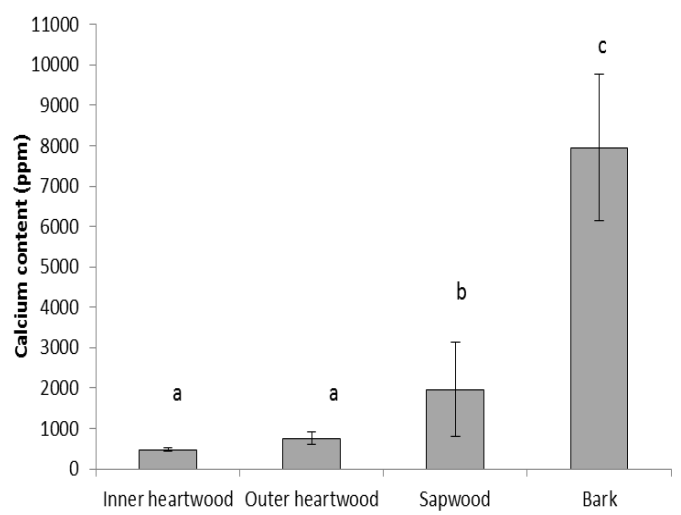

Figure 2. Calcium content (ppm) of Acacia mangium stem by provenance and radial position. Mean of 5 trees (24 years), with the standard deviation in the error bar. The same letters are not significantly different at $p<5 \%$ by Duncan's test. 

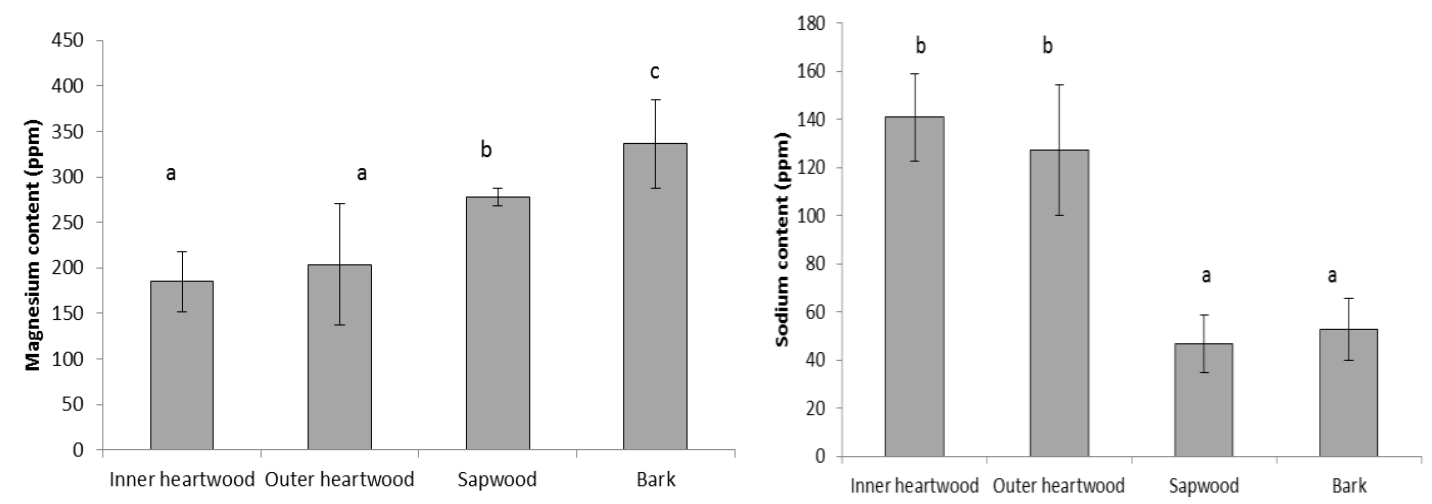

Figure 3. Magnesium and sodium content (ppm) of Acacia mangium stem by radial position. Mean of 5 trees (24 years), with the standard deviation in the error bar. The same letters are not significantly different at $p<5 \%$ by Duncan's test.

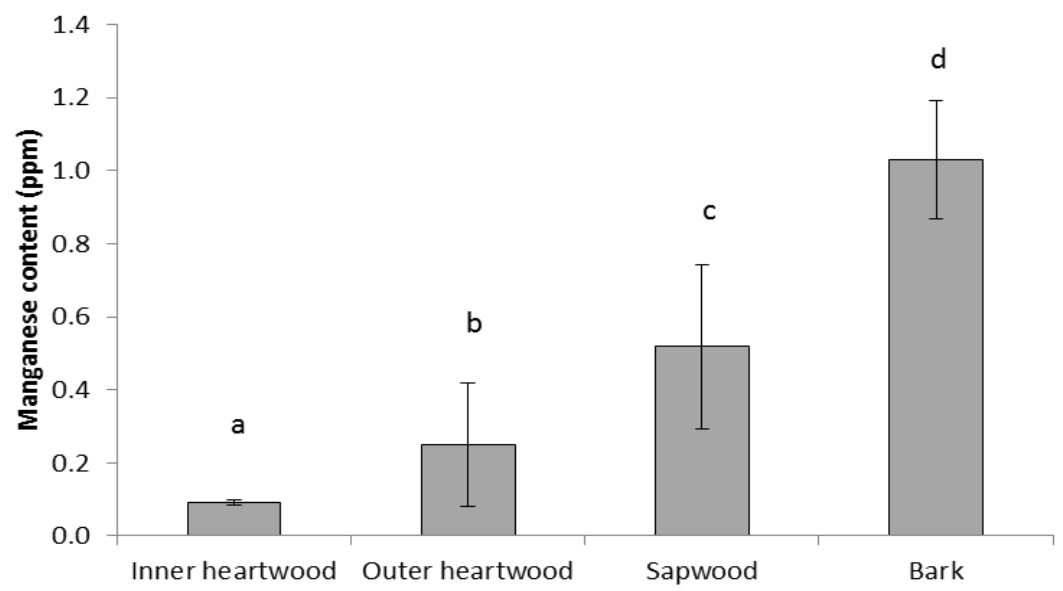

Figure 4. Manganese content (\%) of Acacia mangium stem by radial position. Mean of 5 trees (24 years), with the standard deviation in the error bar. The same letters are not significantly different at $p<5 \%$ by Duncan's test.

Relationship between Extractive Compounds and Total Extractive Contents

The correlation between the parameters of each stem part is presented in Table 3-5. In the heartwood part, the strongest relationship was observed between $\mathrm{Ca}$ and $\mathrm{Mg}$ content $\left(r=0.63^{\star *}\right)$ among inorganic elements, and ash content correlated moderately with $\mathrm{K}$ content $\left(r=0.30^{*}\right)$. A negative moderate relationship was measured between ash and insoluble acid content $\left(r=-0.41^{*}\right)$ for the sapwood region. Only a few significant relationships were found for the inorganic element and silica in the same region, i.e. between insoluble acid ash and $\mathrm{K}$ content $\left(\mathrm{r}=-0.44^{*}\right)$. In the bark part, moderate positive correlations were obtained between the ash and $\mathrm{Mn}$ contents $\left(r=0.54^{*}\right)$. Of the inorganic elements-silica, the strongest positive correlation was measured between insoluble acid ash and $\mathrm{Fe}$ contents $\left(\mathrm{r}=0.61^{* \star}\right)$.

There was no common pattern in the correlation between ash and insoluble acid contents for all stem parts. Therefore, the variation of silica is independent of ash content, and this is contradictory to the results presented by Abasolo et al. (2001), where a strong correlation between ash and silica contents in several rattan species was obtained ( $r=0.96$ ). Insoluble acid ash level moderately correlated with Fe level in sapwood and bark tissues but negatively correlated with $\mathrm{K}$ in the tissue. Silica affects the cuticular transpiration and $\mathrm{CO}_{2}$ uptake of plants (Abasolo et al. 2001), while $\mathrm{Fe}$ is present in biologically more active parts of the tree. This correlation is interpreted to mean that Fe and silica may be more active due to the high number of living cells in sapwood and inner bark parts.

It is also noticed that positive moderate correlations were observed between $\mathrm{Mg}$ and $\mathrm{Ca}$ contents in heartwood $\left(r=0.63^{* *}\right)$ and bark $\left(r=0.54^{* *}\right)$ regions. $\mathrm{Mg}$ and $\mathrm{Ca}$ belong to the alkaline earth metal group (IIA). This correlation may be linked to the role of the two elements in cell and membrane production (Kramer and Kozlowsky 1960; Okada et al. 1987; Cutter and Guyette 1993). Furthermore, it should be noted that the values in the bark part are influenced by atmospheric deposition. However, it is not known why such a correlation was not observed in the sapwood region. 
Table 3. Pearson's correlation among ash content and inorganic element contents in Acacia mangium sapwood

\begin{tabular}{lccccccc}
\hline Content & Acid insoluble ash & Iron & Potassium & Calcium & Magnesium & Natrium & Manganese \\
\hline Ash & $-0.41^{*}$ & 0.09 & $0.39^{*}$ & -0.32 & 0.01 & -0.38 & -0.36 \\
Acid insoluble ash & & $0.42^{*}$ & $-0.44^{*}$ & 0.40 & -0.25 & -0.07 & 0.09 \\
Iron & & & 0.24 & -0.04 & -0.21 & -0.01 & -0.07 \\
Potassium & & & & -0.23 & 0.31 & -0.26 & -0.26 \\
Calcium & & & & & 0.32 & 0.32 & 0.00 \\
Magnesium & & & & & & 0.14 & -0.34 \\
Sodium & & & & & & & 0.34 \\
\hline
\end{tabular}

Table 4. Pearson's correlation among ash content and inorganic element contents in Acacia mangium heartwood

\begin{tabular}{lccccccc}
\hline Content & Acid insoluble ash & Iron & Potassium & Calcium & Magnesium & Natrium & Manganese \\
\hline Ash & 0.28 & 0.17 & $0.30^{*}$ & 0.00 & 0.26 & 0.19 & 0.11 \\
Acid insoluble ash & & 0.08 & 0.14 & -0.24 & -0.19 & -0.16 & 0.10 \\
Iron & & & $0.44^{* *}$ & -0.19 & -0.16 & 0.06 & 0.17 \\
Potassium & & & & 0.16 & 0.26 & 0.29 & 0.09 \\
Calcium & & & & & $0.63^{* *}$ & $0.35^{*}$ & $-0.29^{*}$ \\
Magnesium & & & & & & $0.42^{* *}$ & $-0.35^{*}$ \\
Sodium & & & & & & & -0.10 \\
\hline
\end{tabular}

Table 5. Pearson's correlation among ash content and inorganic element contents in Acacia mangium bark

\begin{tabular}{lccccccc}
\hline Content & Acid insoluble ash & Iron & Potassium & Calcium & Magnesium & Natrium & Manganese \\
\hline Ash & $0.44^{*}$ & 0.34 & 0.09 & 0.30 & 0.28 & -0.15 & $0.54^{*}$ \\
Acid insoluble ash & & $0.61^{* *}$ & 0.11 & -0.10 & 0.14 & 0.24 & -0.22 \\
Iron & & & 0.11 & -0.22 & 0.07 & 0.20 & -0.27 \\
Potassium & & & & 0,29 & 0.41 & -0.12 & 0.21 \\
Calcium & & & & & $0.54^{* *}$ & 0.22 & -0.22 \\
Magnesium & & & & & & 0.02 & 0.20 \\
Sodium & & & & & & & 0.10 \\
\hline
\end{tabular}

Remark: ${ }^{* *}$ Significant at the $1 \%$ level; ${ }^{*}$ significant at the $5 \%$ level

\section{Conclusions}

The ash, silica, and inorganic element contents of mangium wood were measured to evaluate the effect of provenance and radial position factors. The ash content ranged $0.5 \sim 1.1 \%$, and $2.5 \sim 4.7 \%$ for wood and bark respectively. A significant interaction was observed for ash content where the lowest level was found in the wood of ElArish provenance. Furthermore, the amounts of insoluble acid ash content were $300-5800$ and $4000-6000$ ppm for wood and bark respectively, with provenance and radial position significant influencing factors. The highest amount was observed in El-Arish samples. The results of inorganic element measurement were $\mathrm{Fe}$ 0 500 ppm (wood) and 28 384 ppm (bark); K 40 311 ppm (wood) and 210 250 ppm (bark); Ca 130 5850 ppm (wood) and 3919 11746 ppm (bark); Mg 0 500 ppm (wood) and 28 384 ppm (bark); $\mathrm{Na}$ 35 65-168 ppm (wood) and 38 70 ppm (bark); Mn $0.05 \sim 1.27 \mathrm{ppm}$ (wood) and 0.52 1.41 ppm (bark). The significant interaction between provenance and radial position factors was measured in $\mathrm{K}$ content. Ash content was negatively moderately correlated with insoluble acid on a moderate level in the sapwood. On a positive level with insoluble acid ash content, the bark was moderately correlated. Meanwhile, moderate correlations were calculated between $\mathrm{Mg}$ and $\mathrm{Ca}$ contents in heartwood and bark regions. In the sapwood region, the highest correlation degree was between insoluble acid ash and $\mathrm{K}$ contents. The comparatively low values of ash and acid soluble ash contents of El-Arish provenance make it is more suitable for improving wood quality by tree breeding.

\section{Acknowledgements}

This research was carried out with support from DPP Grant 2011 Faculty of Forestry UGM. The authors would like to thank IGN Danu Sayudha and Lukas Gustomo for technical assistances.

\section{References}

Abasolo, W.P.; M. Yoshida; H. Yamamoto; T. Okuyama. 2001. Silica in Several Rattan Species. Holzforschung 55: $595-600$.

ASTM International. 2002. D1102 Test Methods for Ash in Wood. Annual Book of ASTM Standards 2002, Section 4: Construction. West Conshohocken, PA. p. 175.

CABI. 1996. PROSEA Timber Trees. CABI Publishing. 
Cutter, B.E.; R.P. Guyette. 1993. Anatomical, Chemical and Ecological Factors Affecting Tree Species Choice in Dendrochemistry Studies. Journal of Environmental Quality 22: 611-619.

De Silva, D.; W.E. Hillis. 1980. The Contribution of Silica to the Resistance of Wood to Marine Borers [Syncarpia glomulifera, turpentine, Bankia australis]. Holzforschung 34(3): 95-97.

Fengel, D.; G. Wegener. 1984: Wood chemistry, Ultrastructure, Reactions. Walter de Gruyter, Berlin.

Firmanti, A.; K. Komatsu; S. Kawai. 2007. Effective Utilization of Fast-growing Acacia mangium Willd Timber as a Structural Material. Jurnal IImu dan Teknologi Kayu Tropis 5: 29-37.

Hadjib, N.; Y.S. Hadi; D. Setyaningsih. 2007. Sifat Fisis dan Mekanis Sepuluh Provenans Kayu Mangium (Acacia mangium Willd.) dari Parung Panjang, Jawa Barat. Jurnal IImu dan Teknologi Kayu Tropis 5: 7-11.

Kanazawa, H.; T. Nakagami; K. Nobashi; T. Yokota. 1978. Studies on the Gluing of the Wood. Articles. XI. The Effects of Teak Wood Extractives on the Curing Reaction and the Hydrolysis Rate of the Urea Resin. Mokuzai Gakkaishi 24: 55-59.

Kramer, P.J.; T.T. Kozlowsky, 1960. Physiology of Trees. McGraw-Hill Book Company, Inc. New York Toronto London.

Kjær, E.D.; S. Kajornsrichon; E.B. Lauridsen. 1999. Heartwood, Calcium and Silica Content in Five Provenances of Teak (Tectona grandis L.). Silvae Genetica 48: 1-3.

Korai, H.; P. Nigel; T. Liem. 2000. Properties of Acacia mangium Particle Board II. Proceedings the 4th Pacific Rim Bio-based Composite Symposium. Bogor. pp. 189-194.

Kuhn, A.J.; W.H. Schröder, J. Bauch. 1997. On the Distribution and Transport of Mineral Elements in Xylem, Cambium, and Phloem of Spruce (Picea abies [L.] Karst.). Holzforschung 51(6): 487-496.

Lukmandaru, G.; T. Ashitani, K. Takahashi 2009. Color and Chemical Characterization of Partially Black-Streaked Heartwood in Teak (Tectona grandis L.f.). Journal of Forestry Research 20: 377-380.

Lukmandaru, G.; L.S. Gustomo; I.G.N.D. Sayudha, V.E. Prasetyo. 2011a. Studi Keasaman dan Kapasitas Penyangga pada Kayu Mangium. Prosiding Seminar Nasional MAPEKI XIII, Bali, p. 388-396.

Lukmandaru, G., I.G.N.D. Sayudha; L.S. Gustomo; V.E. Prasetyo. 2011b. Pengukuran Kadar Ekstraktif dan Sifat Warna Kayu Acacia mangium dari Lima Provenans. Prosiding Seminar Nasional MAPEKI XIII, Bali, p. 372-380.

Lukmandaru, G. 2012. Komposisi Ekstraktif pada Kayu Mangium (Acacia mangium). Jurnal IImu dan Teknologi Kayu Tropis 10(2): 150-158.

Minato, K.; T. Morita. 2005. Blackening of Diospyros Genus Xylem in Connection with Boron Content. Journal Wood Science 5: 659-662.
Martínez-Pérez, R.; F.E. Pedraza-Bucio; R. OrihuelaEquihua; P. López-Albarrán; J.G. Rutiaga-Quiñones. 2015. Calorific Value and Inorganic Material of Ten Mexican Wood Species. Wood Research 60 (2): 281-292.

Meerts, P. 2002. Mineral Nutrient Concentrations in Sapwood and Heartwood: A Literature Review. Annals of Forest Science 59: 713-722.

Nugroho, D.N.; S.N. Marsoem; K. Yasue; T. Fujiwara; T. Nakajima; M. Hayakawa; S. Nakaba; Y. Yamagishi; H.O. Jin; T. Kubo; R. Funada. 2012. Radial Variations in the Anatomical Characteristics and Density of the Wood of Acacia mangium of Five Different Provenances in Indonesia. Journal of Wood Science 58: 185-194.

Okada, N.; Y. Katayama; T. Nobuchi; Y. Ishimaru; H. Yamashita; A. Aoki. 1987. Trace Elements in the Stems of Trees I. Radial Distributions in Sugi (Cryptomera japonica D. Don). Mokuzai Gakkaishi 33(12): 913-920.

Okada, N.; Y. Katayama; T. Nobuchi; Y. Ishimaru; A. Aoki. 1993a. Trace Elements in the Stems of Trees V. Comparisons of Radial Distributions among Softwood Stems. Mokuzai Gakkaishi 39(10): 1111-1118.

Okada, N.; Y. Katayama; T. Nobuchi; Y. Ishimaru; A. Aoki. 1993b. Trace Elements in the Stems of Trees VI. Comparisons of Radial Distributions among Hardwood Stems. Mokuzai Gakkaishi 39(10): 1119-1127.

Passialis, C.; E. Voulgaridis; S. Adamopoulos; M. Matsouka. 2008. Extractives, Acidity, Buffering Capacity, Ash and Inorganic Elements of Black Locust Wood and Bark of Different Clones and Origin. Holzs als Roh-und Werkstoff 66: 395-400.

Raphy, K.M.M.; E.V. Anoop; P. Aruna; V.V. Sheena; V. Ajayghosh. 2011. Provenance Variation in Wood Chemical Properties of Acacia mangium Willd. and Acacia auriculiformis Cunn., Grown in a Wet Humid Site in Thrissur District of Kerala, South India. Journal of Indian Academy of Wood Science 8(2): 120-123.

Shanavas, A.; B.M. Kumar. 2003. Fuelwood Characteristics of Tree Species in Homegardens of Kerala, India. Agroforestry Systems 58(1): 11-24.

Sjostrom, E. 1981. Wood Chemistry: Fundamentals and Applications. Academic Press, New York, p. 102.

Shmulsky, R.; P.D. Jones. 2011. Forest Products and Wood Science: An Introduction, Sixth Edition. John Wiley \& Sons, Inc. p. 45.

Subyakto, L.; Suryanegara; Sudijono; M. Gopar; B. Prasetya, B. Subiyanto. 2003. Development of Binderless Particleboard from Acacia mangium Bark. International Symposium on Sustainable Utilization of Acacia mangium. JSPS-LIPI Core University Program. p. 119-123.

Subyakto, L.; Suryanegara; M. Gopar; K.W. Prasetiyo. 2005. Utilization of Acacia (Acacia mangium_Willd) Bark for Particleboard with Low Phenol Formaldehyde Content. Jurnal IImu dan Teknologi Kayu Tropis 3: 20-23. 
Syafii, W.; I.Z. Siregar. 2006. Sifat Kimia dan Dimensi Serat Mangium (Acacia mangium_Willd.) dari Tiga Provenans. Jurnal IImu dan Teknologi Kayu Tropis 4: 28-32.

Takahashi, K. 1996. Relationships between the Blacking Phenomenon and Norlignans of Sugi (Cryptomeria japonica D. Don.) Heartwood I. A Case of Partially Black Heartwood. Mokuzai Gakkaishi 42: 998-1005.

Tsuchiya, Y.; H. Shimogaki; H. Abe; A. Kagawa. 2010. Inorganic Elements in Typical Japanese Trees for Woody Biomass Fuel. Journal of Wood Science 56: 53-63.

TAPPI. 1992. Acid Insoluble Ash Content. TAPPI Test Methods 1992-1993. TAPPI Press, Atlanta, Georgia.
Yano, H.; S. Ogawa; C.M.E. Susanti. 2003. The Direct Conversion of Acacia mangium Bark into Waterproof Wood Adhesives. International Symposium on Sustainable Utilization of Acacia mangium. JSPS-LIPI Core University Program. p. 96-99.

Ganis Lukmandaru, Vendy Eko Prasetyo, Widyanto Dwi Nugroho

Department of Forest Products Technology, Faculty of Forestry, Universitas Gadjah Mada

JI Agro No 1, Bulaksumur, Sleman, 55281

E-mail: glukmandaru@ugm.ac.id 